\title{
MODELING KUALITAS LINGKUNGAN HIDUP DI INDONESIA TAHUN 2017 : SUATU UPAYA PENCAPAIAN SDGS
}

(Pendekatan SEM-PLS)

\author{
(Modeling of Enviromental Quality in Indonesia in 2017 : An Effort to Achieve SDGS) \\ Amelia Rizki Saraswati ${ }^{1}$, Tiodora Hadumaon Siagian ${ }^{2}$ \\ ${ }^{1}$ Badan Pusat Statistik \\ 2Dosen Politeknik Statistika STIS \\ Kampus Politeknik Statistika STIS, Jalan Otto Iskandardinata 64C Jakarta \\ E-mail: ameliarizkis@gmail.com
}

\begin{abstract}
ABSTRAK
Masalah lingkungan di Indonesia menjadi masalah yang kompleks dan dilematis. Keberhasilan pembangunan dan pertumbuhan sosial-ekonomi yang dilaksanakan dengan memanfaatkan sumber daya alam banyak menyisakan dampak negatif terhadap kualitas lingkungan hidup. Hal ini bertentangan dengan tujuan ke 11 dari SDGs yaitu membangun kota dan pemukiman inklusif, aman, tahan lama dan berkelanjutan dimana salah satu caranya adalah dengan memberikan perhatian terhadap keseimbangan ekonomi, lingkungan, dan bidang lainnya. Untuk mengukur kualitas lingkungan hidup, Indonesia memiliki Indeks Kualitas Lingkungan Hidup (IKLH) yang juga merupakan evaluator umum kualitas lingkungan hidup negara. IKLH terdiri dari Indeks Kualitas Air (IKA), Indeks Kualitas Tutup Lahan (IKTL), dan Indeks Kualitas Udara (IKU). Dari tahun 20162017 kenaikan hanya terjadi pada IKU, sedangkan IKA dan IKTL tidak. Hal tersebut berimbas pada IKLH nasional yang hanya mengalami kenaikan sedikit, sehingga kondisi lingkungan Indonesia masih terbilang buruk. Berdasarkan Environmental Performance Index (EPI), Indonesia menempati urutan ke 133 dari 178 negara dengan nilai sebesar 46,92. Peringkat tersebut mengindikasikan bahwa kualitas lingkungan hidup di Indonesia masih tergolong rendah. Oleh karena hal itu, penelitian ini penting dilakukan untuk melihat gambaran kondisi lingkungan hidup di Indonesia dan variabel-variabel yang memengaruhi kualitas lingkungan hidup di Indonesia. Penelitian ini menggunakan pendekatan metode structural equation modelling- partial least square (SEM-PLS). Variabel-variabel yang digunakan adalah variabel laten daya dukung lingkungan, kerusakan kota, dan perilaku. Dari hasil pengolahan data didapatkan: variabel yang signifikan memengaruhi kualitas lingkungan adalah variabel daya dukung lingkungan dan variable laten kerusakan kota. Dua variabel tersebut memengaruhi kualitas lingkungan secara negatif.
\end{abstract}

Kata kunci: kualitas lingkungan, SEM PLS, Indonesia

\begin{abstract}
Environmental problems in Indonesia become a complex and dilemma problem. The success of development and socio-economic growth carried out by utilizing natural resources leaves many negative impacts on the quality of the environment. This contradicts the 11th goal of the SDGs, which is to build cities and settlements that are inclusive, safe, durable and sustainable in which one way is to pay attention to economic balance, the environment and other fields. To measure the quality of the environment, Indonesia has an Environmental Quality Index (IKLH) which is also a general evaluator of the country's environmental quality. IKLH consists of Water Quality Index (IKA), Land Cover Quality Index (IKTL), and Air Quality Index (IKU). From 2016-2017 the increase only occurred at KPI, whereas IKA and IKTL did not. This has an impact on the national IKLH which has only increased slightly, so that Indonesia's environmental conditions are still fairly poor. Based on the Environmental Performance Index (EPI), Indonesia ranks 133 th out of 178 countries with a value of 46.92. The rating indicates that the quality of the environment in Indonesia is still relatively low. Therefore, this research is important to do to know the environmental conditions in Indonesia and the variables that affect the quality of the environment in Indonesia. This study uses the structural equation modeling approach - partial least square (SEM-PLS). The variables used are latent variables carrying capacity of the environment, urban damage, and behavior. From the results of data processing, it is found that the variables that significantly affect the quality of the environment are the environmental carrying capacity variable and the latent variable of city damage. These two variables negatively affect environmental quality.
\end{abstract}

Keywords: environmental quality, PLS SEM, Indonesia 


\section{PENDAHULUAN}

Masalah lingkungan di Indonesia menjadi masalah yang kompleks dan dilematis. Keberhasilan pembangunan dan pertumbuhan sosial-ekonomi yang dilaksanakan dengan memanfaatkan sumber daya alam banyak menyisakan dampak negatif terhadap kualitas lingkungan. Hal ini bertentangan dengan tujuan ke 11 dari SDGs yaitu membangun kota dan pemukiman inklusif, aman, tahan lama dan berkelanjutan dimana salah satu caranya adalah dengan memberikan perhatian terhadap keseimbangan ekonomi, lingkungan, dan bidang lainnya. Menurut Hadi (1998) terdapat 4 prinsip untuk mewujudkan pembangunan berkelanjutan yang meliputi: pemenuhan kebutuhan dasar, pemeliharaan lingkungan, keadilan social yang berupa keadilan untuk generasi yang akan datang, dan kesempatan untuk menentukan nasib sendiri. Berdasarkan Environmental Performance Index (EPI), Indonesia menempati urutan ke 133 dari 178 negara dengan nilai sebesar 46,92. Peringkat tersebut mengindikasikan bahwa kualitas lingkungan hidup di Indonesia masih tergolong rendah. Oleh karenanya, jika kualitas lingkungan buruk, maka sumber-sumber lain yang menjadi prinsip untuk pembangunan akan semakin menipis dan sulit dicapai. Akibatnya, kerusakan lingkungan akan mengancam tidak saja terhadap keberlanjutan pembangunan itu sendiri tetapi juga akan mengancam eksistensi keberadaan manusia. Dampak jangka panjangnya adalah keseimbangan yang menjadi syarat pembangunan kota berkelanjutan sesuai dengan tujuan ke 11 SDGs menjadi tidak tercapai.

Untuk mengukur kualitas lingkungan, Kementrian Lingkungan Hidup dan Kehutanan (KLHK) bekerja sama dengan Badan Pusat Statistik (BPS) menghitung Indeks Kualitas Lingkungan Hidup (IKLH) yang merupakan evaluator umum kualitas lingkungan hidup negara. IKLH terdiri dari 3 dimensi penyusun yaitu Indeks Kualitas Air (IKA), Indeks Kualitas Tutup Lahan (IKTL), dan Indeks Kualitas Udara (IKU). Data tahun 2016-2017 menunjukkan bahwa kenaikan hanya terjadi pada IKU sebesar 5,42\%, sedangkan IKA dan IKTL justru mengalami penurunan berturut-turut $1,7 \%$ dan $0,95 \%$. Hal tersebut berimbas pada IKLH nasional yang hanya mengalami kenaikan sedikit sebesar 0,73\%, sehingga di tahun 2017 IKLH Indonesia berada di angka 66,46 atau dengan kata lain berdasarkan dokumen Rancangan Pembangunan jangka Menengah Nasional RPJMN (2015), IKLH masih belum memenuhi target RPJMN 2015-2019 sebesar 66,5. Oleh karena hal itu, penelitian ini penting dilakukan untuk melihat gambaran kondisi lingkungan hidup di Indonesia dan variabelvariabel apa saja yang memengaruhi secara signifikan kualitas lingkungan hidup di Indonesia.

Beberapa penelitian tentang lingkungan hidup telah dilakukan, di antaranya adalah penelitian kualitas lingkungan oleh Hui Di, dkk ( 2018) tentang faktor-faktor yang memengaruhi kualitas lingkungan yaitu jumlah total polusi suara (TTNEM), indeks polusi suara per kapita (ATNEM), kepadatan penduduk, dan area fungsional. Selanjutnya menurut Anis (2016), faktor-faktor yang memengaruhi kualitas lingkungan salah satunya adalah faktor sosial yang ditinjau dari kepadatan penduduk dan jumlah kendaraan bermotor. Menurut Findayani (2015), bencana alam terutama banjir menyebabkan kerusakan lingkungan salah satunya adalah pencemaran air dan sanitasi. Selanjutnya penelitian Pratama (2015), lahan terbangun menyebabkan konflik kepentingan guna lahan yang mengakibatkan permasalahan lingkungan. Dari beberapa literatur yang sudah ada, variabel-variabel yang digunakan dalam penelitian ini adalah variabel laten perilaku ketidakpedulian, daya dukung lingkungan, dan kerusakan lingkungan. Penelitian-penelitian yang sudah ada meneliti secara langsung kualitas lingkungan hidup melalui variable-variabel yang dapat teramati. Sedangkan ada kemungkinan kualitas lingkungan hidup dipengaruhi oleh sesuatu abstrak yang tidak dapat diukur secara langsung (laten). Berangkat dari beberapa kelemahan di penelitian yang sudah ada, maka penelitian ini ingin menghadirkan sesuatu yang baru dalam pemodelan kualitas lingkungan hidup melalui variabel laten dan pemodelan langsung maupun tidak langsung. Penelitian ini bertujuan melihat gambaran kualitas lingkungan hidup di Indonesia dan menganalisis variabelvariabel apa saja yang memengaruhi secara signifikan kualitas lingkungan hidup di Indonesia tahun 2017 serta besaran pengaruh tiap variabelnya. 


\section{METODE}

Penelitian ini merupakan penelitian yang bertujuan melihat gambaran kualitas lingkungan hidup di Indonesia serta menganalisis variabel-variabel yang signifikan memengaruhi kualitas lingkungan hidup di Indonesia tahun 2017. Unit analisis pada penelitian ini adalah provinsi. Penelitian ini menggunakan tiga variabel laten eksogen dan satu variabel laten endogen. Variabel eksogen pada penelitian ini, yaitu perilaku ketidakpedulian, daya dukung lingkungan, dan kerusakan lingkungan. Sedangkan variabel endogen pada penelitian ini adalah kualitas lingkungan hidup.

Tabel 1. Variabel dalam penelitian

\begin{tabular}{|c|c|}
\hline Variabel Laten & Variabel Manifest \\
\hline \multirow{3}{*}{$\begin{array}{l}\text { Kualitas Lingkungan } \\
\text { Hidup }\end{array}$} & Indeks Kualitas Air (IKA) \\
\hline & Indeks Kualitas Udara (IKU) \\
\hline & Indeks Kualitas Tutup Lahan (IKTL) \\
\hline \multirow[t]{7}{*}{$\begin{array}{l}\text { Perilaku } \\
\text { Ketidakpedulian }\end{array}$} & $\begin{array}{l}\text { Persentase rumah tangga yang tidak menghemat air } \\
\text { ketika mencuci pakaian }\end{array}$ \\
\hline & $\begin{array}{l}\text { Persentase rumah tangga yang mencuci alat makan } \\
\text { dengan air mengalir }\end{array}$ \\
\hline & $\begin{array}{l}\text { Persentase rumah tangga yang tidak memanfaatkan } \\
\text { air bekas }\end{array}$ \\
\hline & $\begin{array}{l}\text { Persentase rumah tangga yang membiarkan air } \\
\text { mengalir ketika tidak digunakan }\end{array}$ \\
\hline & Rata-Rata proporsi lampu hemat energi \\
\hline & $\begin{array}{l}\text { Persentase rumah tangga yang jarang mematikan } \\
\text { lampu ketika tidak digunakan }\end{array}$ \\
\hline & $\begin{array}{l}\text { Persentase rumah tangga yang memanfaatkan } \\
\text { cahaya matahari untuk sebagian kecil ruangan }\end{array}$ \\
\hline \multirow{2}{*}{$\begin{array}{l}\text { Daya Dukung } \\
\text { Lingkungan }\end{array}$} & Kepadatan penduduk \\
\hline & Lahan bukan hijau \\
\hline \multirow{2}{*}{$\begin{array}{l}\text { Kerusakan } \\
\text { Lingkungan }\end{array}$} & Jumlah bencana alam \\
\hline & Jumlah kendaraan bermotor \\
\hline
\end{tabular}

Metode Pengumpulan Data

Penelitian ini menggunakan data sekunder publikasi BPS. Data yang digunakan untuk variabel endogen adalah publikasi IKLH 2017. Data dalam publikasi ini menggambarkan kondisi kualitas air, kualitas udara, dan kualitas tutupan lahan pada 34 provinsi yang pengukurannya dilakukan pada tahun 2017. Kualitas air diukur pada sungai prioritas nasional di 34 provinsi, kualitas udara diukur pada kawasan-kawasan perumahan, transportasi, industri, dan perkantoran di kabupaten/kota, sedangkan kualitas tutupan lahan dihitung berdasarkan indeks tutupan lahan. Untuk variabel perilaku adalah data publikasi IPKLH 2018 Setiap tiga tahun sekali BPS mengadakan Survei Sosial Ekonomi Nasional Modul Ketahanan Sosial (Susenas Modul Hansos). Perilaku rumah tangga yang diamati dibagi ke dalam beberapa blok atau dimensi yang nantinya akan digunakan dalam menghitung tingkat ketidakpedulian terhadap lingkungan.

Untuk variabel daya dukung lingkungan adalah data publikasi Statistik Indonesia 2018. Daya dukung lingkungan terdiri dari daya kapasitas dan daya tampung dimana di penelitian ini menggunakan data kepadatan penduduk dan kesediaan lahan (hutan dan perairan). Variabel kerusakan kota juga menggunakan data publikasi Statistik Indonesia 2018 yaitu data jumlah kendaraan bermotor sedangkan data jumlah bencana alam berasal dari Statistik Badan Nasional Penganggulangan Bencana (BNPB) 2018.

Metode Analisis

Analisis dilakukan dengan analisis deskriptif melalui peta tematik, sedangkan untuk melihat variabel yang berpengaruh dan besaran pengaruhnya dilakukan pendekatan dengan metode structural equation modelling- partial least square (SEM-PLS) dengan menggunakan tiga variabel 
laten eksogen dan satu variabel laten endogen. Variabel eksogen pada penelitian ini, yaitu perilaku ketidakpedulian, daya dukung lingkungan, dan kerusakan lingkungan. Sedangkan variabel endogen pada penelitian ini adalah kualitas lingkungan hidup. Dalam SEM-PLS, ada 2 tahapan yang harus dilakukan, yaitu evaluasi model pengukuran dan evaluasi model struktural. Pada evaluasi pengukuran, tahapannya yaitu uji validitas dan uji reliabilitas. Sedangkan pada evaluasi structural, tahapannya adalah uji signifikansi dan koefisien jalur. Software yang digunakan adalah SmartPLS versi 2.

Adapun tahapan untuk analisis inferensia dengan pendekatan SEM-PLS adalah sebagai berikut

1. Membuat rancangan outer dan inner model

2. Melakukan evaluasi outer model

Untuk variabel dengan konstruk reflektif :

a. Uji validitas konvergen dengan melihat loading factor

b. Uji validitas diskriminan dengan syarat akar AVE lebih besar dari korelasi antar variabel

c. Uji reliabilitas

Untuk variabel dengan konstruk formatif :

Uji signifikansi tiap variabel manifest dengan nilai VIF harus kurang dari 10

Jika ada variabel yang tidak memenuhi syarat uji di atas, maka dihapuskan dari evaluasi model

3. Melakukan evaluasi inner model
a. Bootstrapping
b. Uji goodness of fit (R square)
c. Membuat persamaan model structural
$\eta=\beta \eta+\Gamma \xi+\varsigma$
Keterangan:
$\eta$ : vector dari variabel endogen,
$\beta$ : matriks koefisien hubungan endogen dan endogen
$\xi$ : vector dari variabel eksogen,
$\Gamma$ : matriks koefisien hubungan eksogen dan endogen,
$\varsigma$ : vector dari kesalahan (error) structural,
$\mathrm{m}$ : banyaknya variabel laten endogen,
$\mathrm{n}$ : banyaknya variabel laten eksogen

\section{HASIL DAN PEMBAHASAN}

Gambaran Indeks Kualitas Lingkungan Hidup (IKLH)

Dari tahun 2016 ke 2017 kenaikan hanya terjadi pada IKU, sedangkan IKA dan IKTL tidak. Hal tersebut berimbas pada IKLH nasional yang hanya mengalami kenaikan sedikit seperti terlihat pada Tabel 2 di bawah ini.

Tabel 2. IKLH Nasional Tahun 2016 dan 2017

\begin{tabular}{|c|l|l|l|l|}
\hline Tahun & IKU & IKA & IKTL & IKLH \\
\hline 2016 & 81,61 & 60,38 & 57,83 & 65,73 \\
\hline 2017 & 87,03 & 58,68 & 56,88 & 66,46 \\
\hline Perubahan & 5,42 & $-1,7$ & $-0,95$ & 0,73 \\
\hline
\end{tabular}

Sumber: Publikasi IKLH Indonesia tahun 2017

Sebagaimana dapat dilihat pada Tabel 2. terlihat Indeks Kualitas Lingkungan Hidup (IKLH) Nasional tahun $2017(66,46)$ menunjukkan kenaikan sebesar 0,73 dibanding dengan IKLH Nasional tahun 2016 (65,73). Nilai IKU nasional naik sebesar 5,42 dibandingkan dengan tahun 2016, yaitu dari 81,61 menjadi 87,03 . Nilai IKA nasional turun sebesar 1,70 dibandingkan tahun 2016 , yaitu dari 60,34 menjadi 58,68. Nilai IKTL nasional juga turun sebesar 0,95 dibandingkan dengan tahun 2016, yaitu dari 57,83 menjadi 56,88. Peningkatan nilai IKLH Nasional terjadi karena kontribusi yang besar dari IKU.

Sebaran IKLH dapat dilihat pada Gambar 1. Gambar 1. merupakan peta sebaran IKLH dengan 6 pengklasifikasian, yaitu sangat baik, baik, cukup baik, kurang baik, sangat kurang baik, dan 
waspada. Pengklasifikasian didasarkan pada sebaran nilai IKLH pada 34 provinsi yang mengacu pada publikasi IKLH 2017. Klasifikasi bersifat dinamis sesuai dengan sebaran nilai IKLH pada tiap provinsi. Berdasarkan nilai IKLH tahun 2017, IKLH Nasional tahun 2017 yang memiliki besaran angka 66,49 berada pada predikat Cukup Baik. Dalam peta tematik sebaran ini, 3 provinsi memiliki predikat nilai IKLH Sangat Baik, 13 provinsi dengan predikat Baik, dan 10 provinsi dengan predikat Cukup Baik. Masuk ke kategori bawahnya, ada 1 provinsi dengan predikat Sangat Kurang Baik yaitu Provinsi Daerah Istimewa Yogyakarta dan satu provinsi memiliki status Waspada yaitu Provinsi DKI Jakarta. Pada peta dapat dilihat bahwa nilai IKLH provinsi dengan klasifikasi Cukup Baik, Sangat Kurang Baik, dan Waspada didominasi oleh provinsi-provinsi di Pulau Jawa.

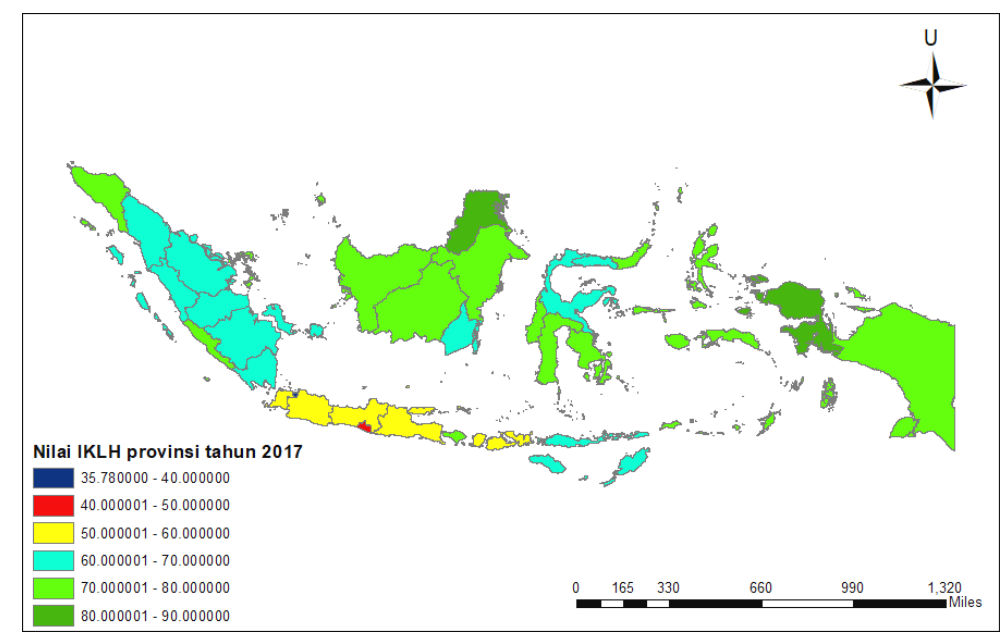

Gambar 1. Peta Tematik IKLH provinsi tahun 2017

Dalam penelitian ini terdapat 6 variabel eksogen. Enam variabel eksogen tersebut masingmasing terdiri dari 1 variabel yang terbentuk dari indicator reflektif, sedangkan 2 lainnya merupakan variabel yang terbentuk dari indicator formatif. Baik reflektif maupun formatif memiliki kriteria evaluasi model pengukuran yang berbeda.

Evaluasi Model Pengukuran (Outer Model)

Untuk menilai model pengukuran pada indikator reflektif, terdapat 3 kriteria yaitu convergent validity, discriminant validity, dan composite reliability. Gambar 2. merupakan output dari SEM-PLS. Untuk melihat tahapan dari model pengukuran indikator reflektif, dapat dilihat pada tanda merah pada Gambar 2. Angka tersebut menunjukkan nilai convergent validity.

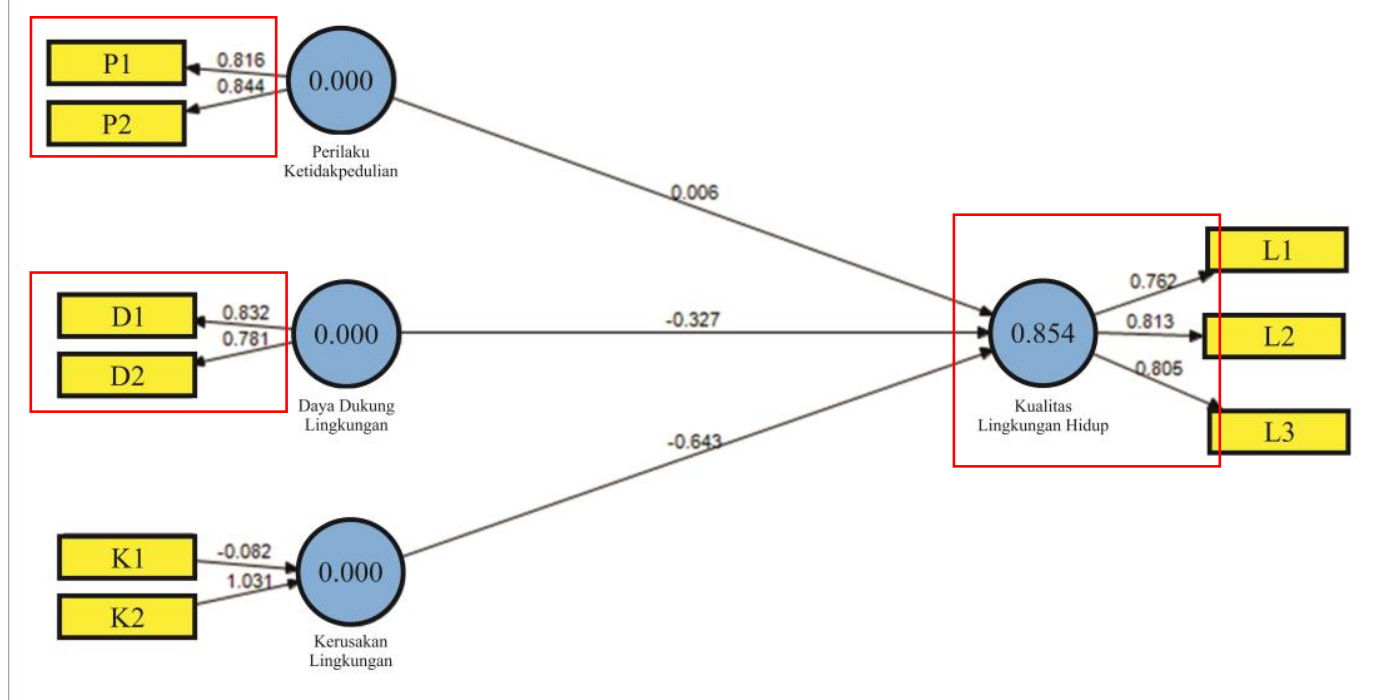

Gambar 2. Output Loading Factor Reflektif 


\section{a. Convergent validity}

Nilai convergent validity diukur dari korelasi antar skor item/komponen dengan skor konstruk. Dalam penghitungan PLS, korelasi ini tergambar pada angka loading factor. Indikator dianggap reliable jika memiliki nilai loading factor $>0,70$. Namun dalam tahap pengembangan di penelitian, nilai 0,50 masih dapat diterima.

Dalam penelitian ini, variabel laten yang dibentuk dari indikator reflektif adalah variabel Kualitas Lingkungan Hidup yang mana merupakan variabel endogen, Perilaku Ketidakpedulian dan variabel Daya Dukung Lingkungan yang merupakan variabel eksogen. Pada awalnya variabel Perilaku Ketidakpedulian memiliki 4 indikator, tetapi setelah dilakukan pengujian hanya 2 indikator yang loading factomya di atas 0,5, maka 2 indikator lain dihapus. Pada Tabel 3. dapat disimpulkan bahwa indikator memiliki convergent validity yang baik karena semua memiliki nilai loading factor di atas 0,5. Hal ini menunjukkan bahwa tiap indicator cukup reliable dalam menggambarkan masingmasing variabel latennya.

Tabel 3. Loading Factor

\begin{tabular}{llll}
\hline $\begin{array}{l}\text { Indikator (Variabel Laten) } \\
\text { perilaku1 <- Perilaku }\end{array}$ & \multicolumn{2}{c}{ Loading Factor } & \multicolumn{2}{l}{ Kesimpulan } \\
perilaku2 <- Perilaku & 0,816 & & Valid \\
DDL1 <- Daya Dukung Lingkungan & 0,844 & Valid \\
DDL2 <- Daya Dukung Lingkungan & 0,832 & Valid \\
Kualitas1 <- Kualitas Lingkungan & 0,781 & Valid \\
Kualitas2 <- Kualitas Lingkungan & 0,762 & Valid \\
Kualitas3 <- Kualitas Lingkungan & 0,812 & Valid \\
\hline
\end{tabular}

\section{b. Discriminant Validity}

Discriminant validity diukur melalui nilai AVE. Kriterianya adalah apabila nilai akar dari AVE tiap konstruk lebih besar dari korelasi antar konstruk di dalam model, maka model dapat dikatakan memiliki discriminant validity yang baik. Tabel 4. menunjukkan nilai AVE dan akar AVE, sedangkan pada Tabel 5. dapat disimpulkan bahwa akar kuadrat AVE untuk tiap variabel laten nilainya lebih besar dari korelasi antar variabel laten. Oleh karena itu model memiliki nilai discriminant validity yang baik.

Tabel 4. AVE dan Akar AVE

\begin{tabular}{lll}
\hline Variabel & AVE & Akar AVE \\
Perilaku & 0,689 & 0,830 \\
Daya Dukung Lingkungan & 0,651 & 0,806 \\
Kualitas Lingkungan & 0,629 & 0,793 \\
\hline
\end{tabular}

Tabel 5. Perbandingan Korelasi antar Variabel Laten dan Akar AVE

\begin{tabular}{|l|c|l|c|}
\hline Variabel Laten & $\begin{array}{l}\text { Daya Dukung } \\
\text { Lingkungan }\end{array}$ & $\begin{array}{l}\text { Kualitas } \\
\text { Lingkungan }\end{array}$ & Perilaku \\
\hline Daya Dukung Lingkungan & 0,806 & & \\
\hline Kualitas Lingkungan & $-0,844$ & 0,793 & \\
\hline Perilaku & $-0,494$ & 0,560 & 0,830 \\
\hline
\end{tabular}

\section{c. Uji reliabilitas}

Uji reliabilitas dilihat dari nilai composite reliability dari indikator yang mengukur variabel laten. Variabel laten dinyatakan reliable jika memiliki composite reliability $>0,5$. Pada Tabel 6 . dapat dilihat bahwa semua indikator memilki nilai composite reliability di atas 0,5 , sehingga dapat disimpulkan bahwa semua indikator dalam penelitian ini memiliki reliabilitas yang baik. 
Tabel 6. Composite Reliability

\begin{tabular}{|l|c|}
\hline \multicolumn{1}{|c|}{ Variabel Laten } & $\begin{array}{l}\text { Composite } \\
\text { Reliability }\end{array}$ \\
\hline Kualitas Lingkungan & 0,835 \\
\hline Daya Dukung Lingkungan & 0,788 \\
\hline Perilaku & 0,815 \\
\hline
\end{tabular}

Untuk variabel eksogen yang terbentuk dari model indikator formatif, kriteria pengukurannya dilihat dari signifikansi nilai weight dan multikolonieritas. Untuk melihat signifikansi nilai pada PLS, sebelumnya harus dilakukan prosedur bootstrapping. Gambar 3. merupakan output dari SEM-PLS setelah dilakukan bootstrapping. Untuk melihat tahapan dari model pengukuran indikator formatif, dapat dilihat pada tanda merah pada Gambar 3. Angka tersebut menunjukkan signifikansi nilai weight.

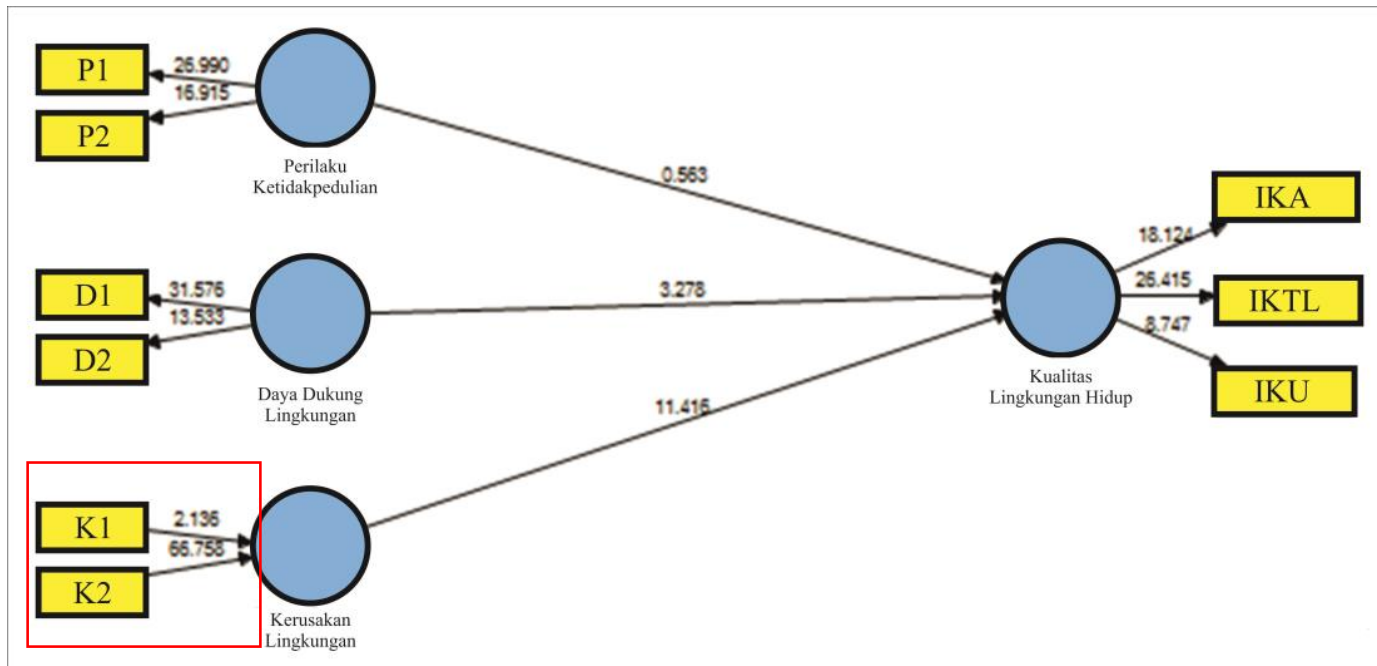

Gambar 3. Output loading factor formatif

a. Signifikansi Nilai Weight

Pada indikator formatif, langkah pertama adalah melihat signifikansi tiap indikator ke variabel latennya.

Hipotesis statistik untuk model pengukuran konstruk formatif :

$\mathrm{H}_{0}: \lambda_{\mathrm{i}}=0$

$\mathrm{H}_{1}: \lambda_{\mathrm{i}} \neq 0$

Keterangan:

$\lambda_{\mathrm{i}}$ : factor loading dari variabel laten ke indikator ke-i

Penolakan $\mathrm{HO}$ akan terjadi jika p-value kurang dari a 5 persen atau 0,05 dan/ nilai t berada pada luar wilayah penerimaan $\mathrm{H}_{0}$. $\mathrm{T}$ kritis (t tabel) adalah sebesar 1,96 (pada alpha 0,05, 2-tailed). Dengan demikian, rentang nilai antara $-1,96 \mathrm{~s} / \mathrm{d}+1,96$ adalah wilayah penerimaan $\mathrm{H}_{0}$, sedangkan diluar itu merupakan wilayah penolakan $\mathrm{H}_{0}$. Berdasarkan output dari SmartPLS, dapat diluhat pada Gambar 3. dan Tabel 7. diperoleh nilai t untuk indikator 'kerusakan1' (variabel jumlah kendaraan bermotor) adalah 2,135 dan nilai t untuk indikator 'kerusakan2' (variabel jumlah bencana alam) adalah 60,758 . Karena nilai $t$ hitung 2,135 dan 60,758 diluar wilayah penerimaan $\mathrm{H}_{0}$, maka dapat disimpulkan bahwa hubungan masing-masing indikator dari variabel laten kerusakan lingkungan ke variabel latennya adalah signifikan.

Tabel 7. Significant Outer Weight

\begin{tabular}{llll}
\hline Variabel Laten & T Statistics & p-value & Ket. \\
\hline
\end{tabular}




\begin{tabular}{llll}
\hline kerusakan1 <- Kerusakan Lingkungan & 2,135 & 0.000 & Signifikan \\
kerusakan2 <- Kerusakan Lingkungan & 60,758 & 0.000 & Signifikan \\
\hline
\end{tabular}

b. Uji Multikolinieritas

Multikolinieritas dapat dilihat dari nilai variance inflation factor (VIF). Jika nilai VIF di atas 10 maka mengindikasikan bahwa terdapat multikolinieritas. Tabel 7 menunjukkan nilai VIF masingmasing indicator formatif. Semua nilai VIF kurang dari 10, sehingga dapat disimpulkan bahwa tidak terdapat multikolinieritas pada semua indikator.

Tabel 8. Nilai VIF

\begin{tabular}{ll}
\hline Variabel Laten & VIF \\
kerusakan1 <- Kerusakan Lingkungan & 1,198 \\
kerusakan 2<- Kerusakan Lingkungan & 1,198 \\
\hline
\end{tabular}

\section{Evaluasi Model Struktural (Inner Model)}

Evaluasi model struktural digunakan untuk melihat hubungan antar variabel laten seperti yang telah dihipotesiskan dalam penelitian, yaitu bagaimana pengaruh variabel-variabel laten terhadap kualitas lingkungan hidup. Hal ditunjukkan dengan melihat nilai R square yang merupakan goodness of fit pada model.

Tabel 9. Nilai $R$ Square

\begin{tabular}{ll} 
Variabel Endogen & $R$ square \\
Kualitas Lingkungan & 0,853 \\
\hline
\end{tabular}

Berdasarkan tabel $R$ square di atas, dapat disimpulkan bahwa dalam model tersebut, kualitas lingkungan dapat dijelaskan oleh variabel-variabel laten Perilaku Ketidakpedulian, Daya Dukung Lingkungan, dan Kerusakan Lingkungan sebesar 85,3 \%. Sementara 14,7 \% lainnya dijelaskan oleh variabel-variabel lain di luar variabel yang digunakan dalam penelitian.

\section{Koefisien Jalur}

Pada model struktural, koefisien jalur menjelaskan seberapa besar hubungan antar variabel. Hipotesis statistik model struktural dari variabel laten eksogen ke variabel laten endogen:

$H_{0}: Y_{i j}=0$

$H_{1}: Y_{i j} \neq 0$

Keterangan :

$Y_{i j}$ : koefisien jalur dari variabel eksogen ke-j ke variabel endogen ke-i.

Penolakan $\mathrm{H}_{0}$ akan terjadi jika $p$-value kurang dari a 5 persen atau 0,05 dan/ nilai t berada pada luar wilayah penerimaan $\mathrm{H}_{0}$. $\mathrm{T}$ kritis (t tabel) adalah sebesar 1,96 (pada a 0,05, 2-tailed). Dengan demikian, rentang nilai antara $-1,96 \mathrm{~s} / \mathrm{d}+1,96$ adalah wilayah penerimaan $\mathrm{H}_{0}$, sedangkan di luar itu merupakan wilayah penolakan $\mathrm{H}_{0}$. Berdasarkan output dari SmartPLS, diperoleh nilai $\mathrm{t}$ untuk variabel daya dukung lingkungan adalah 3,235, untuk variabel kerusakan lingkungan adalah 5,350. Karena nilai t hitung 3,235 dan 5,350 diluar wilayah penerimaan $\mathrm{H}_{0}$ dan $p$-value kurang dari a 0.05 , maka dapat disimpulkan bahwa Daya Dukung Lingkungan dan Kerusakan Lingkungan memiliki hubungan yang signifikan terhadap Kualitas Lingkungan Hidup. Sedangkan untuk variabel Perilaku, karena nilai t hitungnya adalah 0,133 dan $p$-value lebih dari a 0,05 maka variabel perilaku tidak memengaruhi secara signifikan kualitas lingkungan hidup. Selanjutnya untuk penyusunan persamaan structural dari nilai koefisien jalur dapat dilihat pada Tabel 10.

Tabel 10. Koefisien Jalur

\begin{tabular}{|c|c|c|c|c|}
\hline Hubungan & $\begin{array}{c}\text { Koefisien } \\
\text { Jalur }\end{array}$ & T Statistics & $P$-value & Keterangan \\
\hline
\end{tabular}




\begin{tabular}{|l|l|l|l|l|}
\hline $\begin{array}{l}\text { Daya Dukung } \\
\text { Lingkungan }\end{array}$ & $-0,326$ & 3,235 & 0.001 & Signifikan \\
\hline $\begin{array}{l}\text { Kerusakan } \\
\text { Lingkungan }\end{array}$ & $-0,642$ & 5,350 & 0.000 & Signifikan \\
\hline Perilaku & $-0,006$ & 0,113 & 0.910 & $\begin{array}{l}\text { Tidak } \\
\text { Signifikan }\end{array}$ \\
\hline
\end{tabular}

\section{Persamaan Struktural}

$$
\mathbf{n}=-0,326 \gamma_{1} *-0,642 \gamma_{2} *-0,006 \gamma_{3}
$$

(dalam signifikansi $\mathrm{a}=0,05$ )

Pada tabel dan persamaan di atas dapat dilihat bahwa variabel 'Kerusakan Lingkungan' berpengaruh negatif terhadap kualitas lingkungan sebesar -0,642. Dengan kata lain, semakin tinggi kerusakan lingkungan yang terjadi dalam suatu wilayah yang dilihat dari indikator jumlah kendaraan bermotor dan jumlah bencana alam, maka kualitas lingkungan hidupnya akan turun. Hal ini sejalan dengan penelitian Hui Di, dkk yang menyatakan bahwa jumlah total polusi suara (TTNEM) dan indeks polusi suara per kapita (ATNEM) dari kendaraan bermotor dan kepadatan penduduk memengaruhi kualitas lingkungan secara signifikan negatif. Temuan ini juga sejalan dengan penelitian Anis Khoirun Nisa (2016) yang menyatakan bahwa jumlah kendaraan bermotor berpengaruh negatif terhadap kualitas lingkungan hidup Indonesia. Untuk bencana alam, temuan ini sejalan dengan penelitian Kodoatie dan Syarief (2006) yang menyatakan bahwa dampak dari bencana alam terutama kerugian banjir adalah hilangnya nyawa atau terluka, hilangnya harta benda, kerusakan permukiman,kerusakan wilayah perdagangan, kerusakanwilayah industri, kerusakan areal pertanian,kerusakan system drainase dan irigasi,kerusakan jalan dan rel kereta api, kerusakanjalan raya, jembatan, dan bandara, kerusakansystem telekomunikasi, dll.

Sementara itu, variabel Daya Dukung Lingkungan, yang tersusun dari indikator kepadatan penduduk dan luas lahan bukan hijau berpengaruh negatif terhadap kualitas lingkungan hidup sebesar -0,326. Artinya, semakin tinggi beban daya dukung lingkungan, semakin rendah kualitas lingkungan hidupnya. Semakin tinggi kepadatan dan luas lahan bukan hijau yang digunakan, semakin rendah kualitas lingkungannya. Temuan ini sejalan dengan penelitian Anis Khoirun Nisa (2016) yang menyatakan bahwa kepadatan penduduk berpengaruh negatif terhadap kualitas lingkungan hidup Indonesia. Untuk indikator lahan bukan hijau juga sejalan dengan penelitian Ruhimat (2015) yang menyatakan kebutuhan lahan meningkat, luas lahan sangat terbatas, sehingga kemampuan lahan untuk mendukung kehidupan manusia akan cenderung terbatas pula dan akan terjadi penyusutan dan terancam lingkungan (habisnya sumberdaya lain).

Variabel Perilaku Ketidakpedulian tidak memberikan pengaruh yang signifikan dalam model ini. Jadi, dapat disimpulkan bahwa semakin tinggi atau semakin rendah variabel-variabel tersebut tidak memengaruhi kualitas lingkungan hidup di dalam provinsi tersebut. Hal tersebut mungkin disebabkan oleh keterbatasan data Susenas Modul Hansos yang digunakan dalam penelitian ini, dimana data Perilaku adalah data dengan analisis level rumah tangga, dimana 1 responden mewakili pendapat 1 rumah tangga. Dengan kata lain, jawaban dari pertanyaan dalam survei Susenas Modul Hansos tentang variabel perilaku belum bisa mewakili perilaku keseluruhan anggota rumah tangga yang diwawancarai.

\section{KESIMPULAN}

Berdasarkan nilai IKLH rata-rata nasional 2017 sebesar 66,46, ada 10 provinsi yang IKLHnya di bawah angka nasional dan ada 24 provinsi yang memiliki IKLH di atas angka nasional. IKLH tertinggi adalah Provinsi Papua Barat, sedangkan yang terendah adalah DKI Jakarta. Mayoritas provinsi yang memiliki IKLH rendah berada di wilayah Indonesia bagian barat. Variabel-variabel yang terbukti memengaruhi signifikan terhadap kualitas lingkungan adalah variabel laten 'Daya Dukung Lingkungan' yang terdiri dari indikator kepadatan penduduk dan ketersediaan lahan dan variabel laten 'Kerusakan Lingkungan' yang terdiri dari indikator bencana alam dan jumlah kendaraan bermotor. Dua variabel tersebut sama-sama memiliki berpengaruh secara negatif, artinya semakin tinggi variabel daya dukung lingkungan atau semakin tinggi kepadatan penduduk dan ketidaksediaan lahan, maka kualitas lingkungan provinsi tersebut akan menurun. Serta jika semakin tinggi variabel 
kota atau semakin tinggi bencana alam dan jumlah kendaraan bermotor maka kualitas lingkungannya juga rendah. Besaran pengaruh tiap variabel yang memengaruhi secara signifikan yang terbesar adalah variabel 'Kerusakan Kota' yaitu sebesar 64,2\%, sedangkan kontribusi dari variabel 'Daya Dukung Lingkungan' adalah sebesar 32,6\%. Pemerintah perlu meningkatkan upaya perbaikan kualitas lingkungan hidup terutama untuk dimensi air dan tutup lahan mengingat adanya tren penurunan IKA dan IKTL di tahun 2017 dibanding tahun-tahun sebelumnya. Perbaikan kualitas air misalnya dengan penegakan undang-undang tentang penjagaan air bersih. Sedangkan perbaikan tutup lahan dapat dilakukan dengan cara menambah ruang terbuka hijau dan reboisasi hutan. Selain itu, pemerintah juga perlu memerhatikan provinsi-provinsi yang memiliki tingkat kerusakan lingkungan yang tinggi, misal provinsi yang jumlah kendaraan bermotornya tinggi perlu dikeluarkan kebijakan terkait penggunaan transportasi bermotor dan provinsi dengan jumlah kejadian bencana yang banyak perlu diberikan perhatian dan pengawasan yang lebih, misal dengan pemberian sosialisasi ketahanan bencana dan tim tanggap bencana yang banyak.

\section{DAFTAR PUSTAKA}

Badan Pusat Statistik. (2018). Statistik Indonesia 2018. Jakarta : Badan Pusat Statistik

Barry, J., 2007. Environment and Social Theory. Routledge. London.

Di, Hui dkk (2018). Estimation Of The Quality Of An Urban Acoustic Environment Based On Traffic Noise

Evaluation Models.Changchun : Northeast Normal University

Findayani, Aprilia.(2015). Kesiap Siagaan Masyarakat Dalam Penanggulangan Banjir

di Kota Semarang. Semarang : Jurnal Geografi

Ghozali, Imam. (2014). Structural Equation Modeling Metode Alternatif dengan Partial Least Square (PLS) Edisi 3. Semarang: Badan Penerbit Universitas Diponegoro.

Hadi, S. P. (2001). Dimensi lingkungan perencanaan pembangunan. Cet. 1. Bulaksumur, Yogyakarta: Gadjah Mada University Press.

Hair, J.F., Ringle, C.M., dan Sarstedt, M. (2011). PLS-SEM: Indeed A Silver Bullet. Journal of Marketing Theory and Practice, 139-151.

Heimstra, N.W., dan McFarling, L., 1974. Environmental Psychology. Wadsworth. California.

Matos, C. (2018). "Which are the factors that may explain the differences in water and energy consumptions in urban and rural environments?". Elsevier

Miller, Jr. G. T., 1982. Living in The Environment. Wadsworth Publishing Company. California.

Nisaa,Anis Khoirun. (2016) "Analisis Pengaruh Faktor Sosial Ekonomi terhadap Kualitas Lingkungan Hidup Indonesia". Skripsi. Statistik dan Sosial Kependudukan. Politeknik Statistika STIS

Nurhayati, Maika. (2009). "Strategi Optimasi Daya Dukung Sumber Daya Air di Kota Bekasi". Tesis. Universitas Indonesia

Pratama, N.A dkk. (2015). Evaluasi Daya Dukung Lingkungan Berbasis Kemampuan lahan di Kota Batu. Malang : FTP

Pusat Data Dan Informasi Kementerian Lingkungan Hidup Dan Kehutanan. (2017). Indeks Kualitas Lingkungan Hidup Indonesia 2017. Jakarta : Kementerian Lingkungan Hidup Dan Kehutanan

Puspita, Ira. 2016. Pengaruh Perilaku Masyarakat Yang Bermukim di Kawasan Bantaran Sungai Terhadap Penurunan Kualitas Air Sungai Karang Anyar Kota Tarakan. Jakarta : FT Universitas Indonesia

Subdirektorat Statistik Lingkungan Hidup. (2018). Laporan Indeks Perilaku Ketidakpedulian Lingkungan Hidup Indonesia 2018. Jakarta : BPS-RI

Wijanto, Setyo Hari. (2008). Structural Equation Modeling. Yogyakarta : Graha Ilmu

Rahmawati, Linda. (2019). "Kerusakan Lingkungan Hidup dan Pembangunan Infrastruktur" dalam http://www.neraca.co.id/ diunduh pada 10 Juni 2019

Ruhimat, Mamat. (2016). Tekanan Penduduk Terhadap Lahan di Kecamatan Sukaraja Kabupaten Sukabumi. Bandung : FPIPS Universitas Pendidikan Indonesia

Wendling, Zachary A. (2018). "Environmental Performance Index 2018". New Heaven : Yale University 